\title{
EFISIENSI PENGGUNAAN INPUT PAKAN DAN KEUNTUNGAN PADA USAHA TERNAK BABI DI KECAMATAN TARERAN KABUPATEN MINAHASA SELATAN
}

\author{
Rivo E. Kojo ", V.V.J. Panelewen**, M. A.V. Manese ${ }^{* *}$, Nansi Santa**
}

Fakultas Peternakan, Universitas Sam Ratulangi Manado 95115

\begin{abstract}
ABSTRAK
Kecamatan Tareran merupakan salah satu Kecamatan yang terletak di wilayah Kabupaten Minahasa Selatan, terdiri atas 12 (dua belas) desa dan memiliki luas wilayah $7602.45 \mathrm{Ha}$ atau $76024.5 \mathrm{Km}^{2}$.Umumnya masyarakat Tareran berprofesi sebagai petani. Populasi ternak babi terbanyak di Kecamatan Tareran terdapat di 3 desa antara lain Desa Lansot, Desa Rumoong Atas dan Desa Rumoong Atas Dua. Adapun masalah penelitian ini adalah apakah penggunaan biaya produksi dalam usaha ternak babi di Kecamatan Tareran sudah efisien dan memberikan keuntungan. Tujuan penelitian adalah untuk mengetahui jenis dan besarnya biaya produksi dalam usaha ternak babi, menganalisis efisiensi penggunaan input, dan penggunaan input optimum dalam mencapai keuntungan usaha ternak babi. Penelitian ini dilaksanakan di Kecamatan Tareran Kabupaten Minahasa Selatan dengan jumlah responden 30 peternak. Waktu penelitian dan pengumpulan data selama 2 bulan. Data dalam penelitian ini diperoleh dari 2 sumber yaitu data primer dan data sekunder. Metode penentuan sampel dilakukan secara Purposive Sampling atau dilakukan dengan sengaja. Hasil dalam penelitian ini menunjukkan biaya yang dikeluarkan sebesar Rp.18.557.038/periode/tahun dengan

keuntungan sebesar Rp.13.611.309 /periode/tahun. Penggunaan input pakan tidak efisien oleh sebab itu peternak
\end{abstract}

*Alumni Fakultas Peternakan Unsrat

**Jurusan Sosial Ekonomi Peternakan perlu mengurangi pemberian pakan karena sudah berlebihan. Bobot badan yang dicapai berbeda untuk setiap jenis ternak. Penggunaan input dalam mencapai bobot badan maksimum juga berbeda untuk masing-masing ternakmencapai bobot badan maksimum juga berbeda untuk masing-masing ternak.

Kata Kunci: Efisiensi, Input pakan, Keuntungan, Usaha Ternak Babi,Kecamatan Tareran.

\section{ABSTRACT}

\section{FEED EFFICIENCY AND} PROFITABILITY OF PIG FARM AT TARERAN DISTRICT OF SOUTH MINAHASA REGENCY. Tareran district is located in the South Minahasa regency consisted of 12 (twelve) villages and has the area of 7602.45 hectares or $76024.5 \mathrm{Km} 2$. Generally, Tareran community work as farmers. The most pig populations at Tareran district were found at the three villages including villages of Lansot, Rumoong Atas, and Rumoong Atas Dua. The problems of this study are that; first, is the use of production cost in the pig business at the Tareran district efficient? Second, does the production cost provide benefits? Research objectives are to evaluate the type and total cost of production in the pig business at the Tareran district, to analyze the efficiency of input used 
in pig farming, and to determine the optimum use of inputs in achieving the business benefits pigs. The research was conducted in the Tareran district of South Minahasa Regency involving the number of 30 breeders as respondents. Data collections were conducted in the period time of 2 months. The data in this study were obtained from two sources of primary and secondary data. Samples were taken using purposive sampling method. The use of this technique was always based on certain characteristics obtained through the population. The results of these studies showed the production cost of pig farm was Rp18.557.038 per period per year with a gain of about $\mathrm{Rp}$ 13.611.309 per period per year. Inefficient use of food inputs indicating to the farmers need to reduce feeding cost because it caused cost redundancy. It was known that animal body weight achieved was different for each type of pig. In addition, the use of ration inputs to achieve maximum body weight was also different for each animal.

\section{Keywords: Efficiency, Ration Input, Profit, Pig Farm, Tareran District.}

\section{PENDAHULUAN}

Sub sektor peternakan mempunyai peranan penting dalam menunjang kebutuhan masyarakat sebagai sumber bahan makanan dalam bentuk protein hewani. Usaha peternakan babi merupakan salah satu usaha yang menghasilkan produk sebagai sumber protein hewani maupun sumber pendapatan keluarga yang mempunyai arti ekonomi yang sangat penting.

Peningkatan besar usaha atau jumlah ternak yang dipelihara, umumnya para peternak diperhadapkan dengan berbagai kendala. Hal ini terutama terbatasnya modal untuk biaya produksi disamping pemasaran produk ternak serta penguasaan keterampilan beternak yang profesional (Rahardi, dkk. 1999). Sebagian besar peternak memperhitungkan biaya produksi, sebab biaya produksi berhubungan dengan jumlah yang akan diproduksi.

Menurut Sihombing (1997), biaya produksi terbesar dalam usaha ternak babi adalah biaya pakan mencapai 65-80 persen dari total biaya produksi. Kenyataan menunjukkan bahwa semenjak krisis moneter melanda perekonomian, harga bahan pakan ternak terus megalami peningkatan. Adanya kenaikan biaya tanpa diikuti dengan keuntungan merupakan masalah bagi peternak karena biaya produksi merupakan faktor penentu dalam usaha peternakan.

Hasil pra survey di Kecamatan Tareran menunjukkan 
usaha ternak babi yang dilakukan sebagian besar masih bersifat sampingan. Setiap usaha peternakan selalu mengharapkan keuntungan, untuk mencapai harapan tersebut maka perlu memperhitungkan penggunaan input dalam usaha ternak babi. Berdasarkan masalah yang dihadapi peternak babi di Kecamatan Tareran Kabupaten Minahasa Selatan, maka diperlukan suatu kajian efisiensi. Efisiensi yang dimaksud adalah efisiensi ekonomis penggunaan biaya produksi sebagai faktor input dalam hubungannya dengan memperoleh keuntungan.

Berdasarkan latar belakang, maka perumusan masalah dalam penelitian ini yaitu apakah penggunaan biaya produksi dalam usaha ternak babi di Kecamatan Tareran sudah efisien dan memberikan keuntungan. Penelitian ini bertujuan untuk mengetahui jenis dan berapa besar biaya produksi dalam usaha ternak babi, menganalisis efisiensi penggunaan input dalam usaha ternak babi dan penggunaan input optimum dalam mencapai keuntungan usaha ternak babi di Kecamatan Tareran.

\section{MATERI DAN METODE PENELITIAN}

Penelitian telah dilaksanakan pada usaha ternak babi di Kecamatan Tareran yang berlokasi di tiga desa yaitu, Desa Lansot, Desa Rumoong dan Desa Rumoong Atas. Penelitian ini berlangsung selama 1 (satu) bulan terhitung mulai tanggal 18 maret sampai dengan tanggal 18 april 2013.

Penelitian ini dilaksanakan menggunakan metode survey dengan cara mewawancarai secara langsung kepada responden yang telah ditentukan. Sampel ditentukan secara "Purposive Sampling" atau dilakukan dengan sengaja (Mardalis, 1990). Kriteria penentuan sampel dengan ketentuan sebagai berikut : a) peternak masih aktif mengelola usaha ternak babi, b) lama usahanya lebih dari 1 tahun, dan c) Sudah pernah menjual ternak. Banyaknya responden yang diambil adalah sebanyak 30 orang, dari 97 orang peternak. Nama desa dan jumlah responden sebagai sampel dapat dilihat pada Tabel 1. 
Tabel 1. Jumlah Ternak Babi dan Responden

\begin{tabular}{clc}
\hline No & Desa & Responden \\
\hline 1 & Lansot & 10 \\
2 & Rumoong Atas Dua & 15 \\
3 & Rumoong Atas & 5 \\
\hline & Jumlah & 30 \\
\hline
\end{tabular}

Data yang digunakan dalam penelitian ini terdiri atas data primer dan data sekunder. Data primer diperoleh melalui wawancara langsung kepada peternak sebagai responden yaitu meliputi; karakteristik usaha peternakan, jumlah ternak babi, produksi, harga, biaya tetap, biaya variabel selama satu periode produksi atau dalam satu tahun. Data sekunder diperoleh dari instansi, seperti dinas agribisnis Kabupaten Minahasa Selatan, Kantor Kecamatan, Kantor Kelurahan maupun pihak yang ada kaitannya dengan penelitian ini.

Batasan pengukuran dan definisi operasional dalam penelitian ini adalah sebagai berikut :

a. Biaya tetap ialah keseluruhan biaya yang dikeluarkan untuk usaha ternak babi yang selama masa periode produksi tidak mengalami perubahan, yaitu biaya bibit, biaya penyusutan kandang dan peralatan.
1. Biaya bibit yaitu biaya sewa pejantan dihitung dalam satuan rupiah per periode produksi per tahun.

2. Biaya penyusutan kandang dan peralatan yaitu biaya yang dikorbankan selama masa periode produksi dihitung dalam satuan rupiah per periode per tahun.

b. Biaya tidak tetap ialah keseluruhan biaya operasional yang dikeluarkan peternak dalam waktu tertentu yaitu biaya pakan, obat-obatan, air dan listrik.

1. Biaya pakan yaitu hasil kali antara jumlah pakan yang digunakan dengan harga pakan. Pakan ternak babi yaitu jagung, dedak, konsentrat dan lain-lain. Dihitung dalam satuan rupiah per periode per tahun.

2. Biaya obat-obatan/vaksin dan vitamin yaitu hasil kali antara jumlah obat-obatan/vaksin dan vitamin yang digunakan dengan 
harga obat-obatan tersebut, dihitung dalam satuan rupiah per periode per bulan.

3. Biaya tenaga kerja adalah jumlah uang tunai yang dikorbankan dari pemanfaatan tenaga kerja dalam seluruh kegiatan proses produksi dinyatakan dalam rupiah per periode per bulan.

c. Penerimaan ialah hasil penjualan ternak babi dikalikan dengan harga, dinyatakan dalam satuan rupiah per periode per tahun.

d. Keuntungan ialah total penerimaan dikurangi pengeluaran, dinyatakan dalam satuan rupiah per periode per tahun.

Jenis dan besarnya biaya produksi dalam usaha ternak babi di Kecamatan Tareran dianalisis dengan menggunakan persamaan sebagai berikut :

$\mathrm{TC}=\mathrm{TFC}+\mathrm{TVC}$

Keterangan :

TC: biaya total usaha ternak babi (rupiah/periode)

TFC : biaya tetap dalam usaha ternak babi, meliputi biaya bibit, biaya kandang dan peralatan (rupiah/periode)

TVC : biaya tidak tetap dalam usaha ternak babi, meliputi biaya pakan (terdiri atas jagung, biaya dedak, konsentrat), biaya obat- obatan, biaya lain-lain

(terdiri atas listrik dan air)

Analisis efisiensi penggunaan input dalam usaha ternak babi menggunakan persamaan sebagai berikut:

$$
\begin{array}{r}
N P M_{x}=P_{x} \text { atau } \\
\frac{N P M_{x}}{P_{x}}=1 \ldots \ldots \ldots \text { (2) }
\end{array}
$$

\section{Keterangan :}

NPM adalah nilai produk marginal untuk suatu input $\mathrm{P}$ adalah harga input.

Apabila $\frac{N P M_{x}}{P_{x}}>1 ; \quad$ artinya penggunaan input $\mathrm{X}$ belum efisien, sehingga untuk mencapai efisien maka input $X$ perlu ditambah.

Apabila $\frac{N P M_{x}}{P_{x}}<1 \quad$; artinya penggunaan input $\mathrm{X}$ tidak efisien. Untuk menjadi efisien maka penggunaan input $\mathrm{X}$ perlu dikurangi.

Penggunaan input optimum dalam mencapai keuntungan maksimum usaha ternak babi dapat diketahui dengan menggunakan persamaan :

$$
\begin{array}{r}
\Delta Y . P y=\Delta X . P x \\
\operatorname{atau} \frac{\Delta Y}{\Delta X}=\frac{P_{x}}{P_{y}} \ldots \ldots . . . . .
\end{array}
$$

Keterangan :

Y : jumlah produksi ternak babi ( $\mathrm{kg} /$ periode $)$
$\mathrm{X} \quad$ : jumlah input (kg/periode)
$\Delta \mathrm{Y} \quad$ : tambahan jumlah produksi ternak babi
$\Delta \mathrm{X} \quad$ : tambahan jumlah input ternak babi
Py : : harga output
Px : harga input 
$\Delta \mathrm{Y} / \Delta \mathrm{X}:$ produk marjinal

\section{HASIL DAN PEMBAHASAN}

\section{Keadaan Umum Daerah Penelitian} Wilayah Kecamatan Tareran merupakan salah satu Kecamatan yang berada di Kabupaten Minahasa Selatan, merupakan wilayah yang berbukit-bukit. Wilayah Kecamatan Tareran terdiri atas 12 (dua belas) desa dan memiliki luas wilayah $7602.45 \mathrm{Ha}$ atau $76024.5 \mathrm{Km}^{2}$. Batas-batas pemerintahan wilayah Kecamatan Tareran sebagai berikut : Sebelah Utara berbatasan dengan Kecamatan Sulta, Sebelah Selatan berbatasan dengan Kecamatan Amurang Timur, Sebelah Timur berbatasan dengan Kabupaten Minahasa, Sebelah Barat berbatasan dengan Kecamatan Tumpaan.

$$
\text { Jumlah penduduk di }
$$

Kecamatan Tareran pada akhir tahun 2011 tercatat 13.289 jiwa yang terdiri dari penduduk laki-laki sebanyak 6.731 jiwa dan jumlah penduduk perempuan sebanyak 6.478 jiwa. Jumlah penduduk Kecamatan Tareran menurut desadesa yang ada.

Umumnya keadaan peternak di Kecamatan Tareran bervariasi seperti terlihat melalui tingkat umur, tingkat pendidikan, lama usaha, jumlah anggota keluarga dan pekerjaan utama.

\section{Soekartawi}

(2001)

menyatakan bahwa semakin tinggi umur petani peternak maka kemampuan kerja semakin menurun. Berdasarkan hasil penelitian umur peternak bervariasi dari umur 25-65 tahun, kelompok umur yang tertinggi yaitu sebesar 50\%, dan kelompok umur yang paling rendah yaitu umur 56-65 tahun sebesar 10\% dari jumlah keseluruhan peternak. Tingkat pendidikan peternak yang tertinggi yaitu SMP sebesar 23,345 dan tingkat pendidikan peternak yang paling rendah yaitu SD sebesar $13,33 \%$.

Menurut Sumangkut (2006), semakin banyak pengalaman yang dimiliki maka semakin banyak halhal yang diketahui tentang usaha yang dijalankan. Peternak yang ada di Kecamatan Tareran telah memiliki pengalaman dalam menjalankan usaha peternakan babi. Peternak yang menjalankan usaha berkisar 1-5 tahun sebesar 76,67\%, 6-10 tahun sebesar $10 \%$ dan peternak yang menjalankan usahanya 11-20 
sebesar 13,33\% dari jumlah peternak.

Berdasarkan hasil penelitian, jumlah anggota keluarga dari masing-masing peternak di Kecamatan Tareran yaitu peternak yang memiliki 3 anggota keluarga jumlahnya paling banyak sebesar $53,33 \%$, dan paling sedikit adalah peternak yang memiliki 2 dan 5 anggota masing-masing sebesar $10 \%$ dari keseluruhan peternak babi sebagai sampel di Kecamatan Tareran. Jadi, jumlah keseluruhan anggota keluarga 30 responden adalah 101 jiwa yang terdiri atas ayah, ibu dan anak.

Distribusi pekerjaan dari masing-masing responden bervariasi. Ada yang berusaha di bidang usaha tani dan ada pula yang berusaha di luar usaha tani. Salah satu indikator pada tingkat sosial suatu rumah tangga adalah pekerjaan. Hasil penelitian menunjukkan bahwa sebagian besar pekerjaan responden adalah pekerjaan di luar usaha tani ternak yaitu wiraswasta sebesar $33,33 \%$, PNS sebesar 13,33\%, honor daerah dan sopir sebesar 3,33\%, tukang sebesar $10 \%$, dan jenis pekerjaan di dalam bidang usaha tani ternak sebesar $36,68 \%$.

\section{Manajemen Aspek Teknis Usaha Ternak Babi}

Berdasarkan hasil pengamatan, ternak babi yang dipelihara di Kecamatan Tareran yaitu jenis ternak babi Duroc dan Hampshire. Menurut Gultom (2007), ciri-ciri jenis ternak babi Duroc antara lain: tubuh panjang dan besar, warna merah yang bervariasi, mulai dari merah muda sampai merah tua, punggung membentuk busur yang dimulai dari leher sampai ekor, dengan titik tertinggi di tengahtengah, kepala sedang dengan telinga terkulai ke depan dan mukanya agak cekung, produksi susu cukup baik dan banyak anak. Ciri-ciri ternak babi Hampshire antara lain : warna hitam dengan warna putih berbentuk pita yang lebar mengelilingi bahu sampai kedua kaki depan, warna putih ini besarnya sangat bervariasi, punggung mebentuk busur dan kuat, kepala halus dengan rahang yang ramping dan telinga tegak, latak bahu baik dan halus, tubuh halus dan kuat, induk menghasilkan banyak anak dan aktif. 
Desa Rumoong Atas Dua memiliki ternak babi paling banyak yaitu 135 ekor $(48,05 \%)$, sedangkan yang paling sedikit yaitu Desa Rumoong atas dengan jumlah 69 ekor $(24,55 \%)$. Umumnya peternak memiliki ternak babi fase starter dan grower, hal tersebut disebabkan adanya keterbatasan modal dari peternak, sehingga peternak lebih suka menjual ternak babi pada usia \pm 8 (lepas sapih) dan ternak babi usia 5-7 bulan.

Rata-rata produksi ternak babi fase starter dengan rata-rata berat badan $25 \mathrm{~kg} / \mathrm{ekor} /$ periode menggunakan input sebesar 13,88 $\mathrm{kg} /$ periode. Produksi ternak babi fase grower dengan rata-rata bobot badan $105 \mathrm{~kg} / \mathrm{ekor} /$ periode menggunakan input berupa jagung sebesar $142 \mathrm{Kg}$, dedak sebesar $140 \mathrm{~kg}$, dan konsentrat sebesar 74,95 kg. Produksi ternak babi pejantan dengan rata-rata bobot badan 122 kg/ekor/periode menggunakan input jagung sebesar $504 \mathrm{~kg}$, dedak sebesar $712 \mathrm{~kg}$, konsentrat sebesar $480 \mathrm{~kg}$. Produksi ternak babi induk kering dengan ratarata bobot badan 146,35 $\mathrm{kg} / \mathrm{ekor} /$ periode menggunakan jagung sebesar $504 \mathrm{~kg}$, dedak sebesar $712 \mathrm{~kg}$, konsentrat sebesar $480 \mathrm{~kg}$. Produksi ternak babi induk bunting dengan rata-rata bobot badan 137,53 $\mathrm{kg} / \mathrm{ekor} /$ periode menggunakan jagung sebesar $592 \mathrm{~kg}$, dedak $231 \mathrm{~kg}$, konsentrat $181 \mathrm{~kg}$. Produksi ternak babi induk menyusui dengan rata-rata bobot badan 136,14 kg menggunakan jagung sebesar 101 $\mathrm{kg}$, dedak sebesar $84 \mathrm{~kg}$, konsentrat sebesar 54,64 kg.

Berdasarkan hasil penelitian diketahui bahwa pakan yang diberikan pada umumnya ialah jagung, dedak, konsentrat. Terdapat beberapa peternak yang menambah pakan dengan bungkil dan tepung ikan. Harga rata-rata jagung Rp. 3100/kg, dedak Rp.1500/kg, konsentrat Rp. 8500/kg, butiran Rp. 8500/kg, bungkil Rp. 3500/kg, tepung ikan Rp.4000/kg. Pemberian pakan dilakukan rata-rata dua kali sehari yaitu pagi dan sore hari dengan jumlah yang berbeda-beda tergantung dari setiap umur ternak.

Adapun hasil penelitian diperoleh bahwa, untuk ternak babi mulai disapih pada memasuki umur 6 minggu diberikan pakan berupa butiran selama 3 minggu dengan jumlah rata-rata $0,66 \mathrm{~kg} / \mathrm{ekor} / \mathrm{hari}$. 
Ternak babi yang telah memasuki umur 10 minggu (fase grower) mulai diberikan ransum yang dicampur beberapa bahan pakan yaitu, jagung, dedak, konsentrat, bungkil, tepung ikan dan ditambah vitamin. Hasil penelitian menunjukkan bahwa, ratarata konsumsi ternak babi fase grower umur 5-7 bulan sebanyak $1,06 \mathrm{~kg} / \mathrm{hari} / \mathrm{ekor}$, induk kering sebanyak 5,04 kg/ekor/hari, induk bunting sebanyak 9,95 kg/ekor/hari, induk menyusui sebanyak 5,44 $\mathrm{kg} /$ ekor/hari dan pejantan 5,01 kg/ekor/hari. Kondisi ini bila dibandingkan dengan penelitian dari Aritonang (1993) maka pakan yang diberikan terlalu banyak. Aritonang (1993) menyatakan bahwa, untuk umur 8-10 minggu rata-rata 0,83 kg/ekor/hari; umur babi 12-20 minggu rata-rata $1,62 \mathrm{~kg} / \mathrm{ekor} / \mathrm{hari}$, umur babi 21-29 minggu rata-rata $2,74 \mathrm{~kg} / \mathrm{ekor} / \mathrm{hari}$.

Tenaga kerja merupakan salah satu faktor produksi dalam proses produksi pertanian (Sulistyawati, 2009). Hasil penelitian menunjukkan tenaga kerja yang ada dalam usaha ternak babi di Kecamatan Tareran adalah tenaga kerja yang berasal dari dalam keluarga peternak itu sendiri baik suami, istri maupun anak.

Adapun rata-rata curahan waktu kerja per hari dari peternak sampel adalah 3 jam untuk mengerjakan semua pekerjaan dalam usaha ternak babi tersebut. Tetapi, curahan waktu yang dilakukan bila ada ternak babi yang beranak adalah lebih dari 3 jam atau bisa memakan waktu berhari-hari. Adapun rata-rata curahan waktu yang dilakukan oleh peternak antara lain mencampur bahan pakan 35 menit, memberi makan 79 menit, memandikan ternak 38 menit, membersihkan kandang 38 menit. Hal ini berarti curahan waktu kerja per hari per peternak rata-rata 0,34 HOK atau 2,5 sampai dengan 3 jam. Hasil pengamatan untuk biaya tenaga kerja buruh tani di Kecamatan Tareran sebesar Rp.75.000 per hari dengan curahan waktu 8 jam. Biaya yang dikorbankan oleh peternak dengan curahan waktu rata-rata 2,5 sampai dengan 3 jam sebesar Rp. 25.24 per orang atau per peternak.

Penyakit yang sering menyerang ternak babi di Kecamatan Tareran adalah penyakit cacing dan mencret. Ternak babi yang terkena penyakit mencret, biasanya 
responden mengobatinya dengan teramizin dan tizinol yang disuntikan atau dicampur dalam pakan. Pencegahan panyakit dilakukan oleh peternak melalui sanitasi sedangkan vaksinasi dapat diberikan jenis-jenis obat dari kemungkinan timbulnya penyakit.

Tatalaksana pemeliharaan yang dilakukan oleh peternak yaitu pola penanganan intensif dan pada umumnya kandang sudah terbuat dari beton baik dinding kandang maupun lantai. Hasil penelitian menunjukkan bahwa hanya $23,33 \%$ peternak yang menggunakan kandang berdinding bambu. Hal ini dikarenakan keterbatasan modal peternak untuk membuat kandang berdinding beton. Lokasi kandang berada disekitar rumah penduduk masing-masing di belakang rumah yang berjarak dari rumah antara $0-$ 100 meter.

Sistem pemeliharaan ternak babi untuk induk yang akan segera melahirkan di awasi oleh peternak 1 x 24 jam. Anak babi yang baru lahir segera ditolong dan dibersihkan selaput lendir yang menutupi tubuhnya, terutama lubang mulut dan hidung. Tali pusar dipisahkan kira- kira 2,5 $\mathrm{cm}$ dan bekas luka pemotongan diberikan desinfektan berupa obat merah atau betadine.

Anak babi mulai dipisahkan dari induk pada umur 6-8 minggu. Menurut Aritonang (1993) bahwa, anak babi dapat dipisahkan dari induknya sesudah berumur 8 minggu. Penyapihan ini sesuai dengan keadaan dimana induk yang normal masa laktasinya akan berakhir sampai anak babi berumur 8 minggu.

\section{Biaya Produksi, Penerimaan dan Keuntungan Usaha Peternakan Babi di Kecamatan Tareran}

Biaya produksi dalam usaha peternakan babi meliputi biaya tetap dan biaya tidak tetap. Biaya tetap pada usaha peternakan babi meliputi; biaya penyusutan kandang dan peralatan serta perlengkapan kandang, biaya bibit dalam hal ini sewa pejantan. Biaya tidak tetap meliputi; biaya pakan, biaya tenaga kerja, rekening listrik, rekening air, biaya obat-obatan dan vitamin.

Hasil analisis menunjukkan bahwa, biaya tetap sebesar Rp.622.607 atau 3,35\% dari keseluruhan biaya produksi. Biaya tidak tetap sebesar Rp.17.934.431 
atau $96,64 \%$ dari keseluruhan biaya produksi. Berdasarkan hasil penelitian pada masing-masing komposisi biaya selama proses sebesar $26,66 \%$, biaya sewa pejantan sebesar $1,29 \%$, biaya penyusutan kandang dan peralatan sebasar $2,06 \%$, biaya kastrasi sebesar $0,01 \%$, biaya listrik dan air sebesar 3,09\%. Hasil penelitian ini menunjukkan bahwa biaya pakan ternak yang dikorbankan untuk ternak babi di Kecamatan Tareran sesuai dengan pendapat Soekartawi (2001) dan Aritonang (1993). Soekartawi (2001) dan Aritonang mengemukakan bahwa biaya makanan mempunyai persentase terbesar dari keseluruhan biaya produksi yaitu $60-80 \%$.

Rata-rata harga jual ternak babi yang berlaku di Kecamatan Tareran antara lain Rp.23.000/kg berat hidup atau Rp.550.000/ekor. Rata-rata berat hidup ternak untuk produksi per periode per tahun khususnya ialah biaya pakan yaitu sebesar $66.62 \%$. Biaya tenaga kerja fase starter $25 \mathrm{~kg} / \mathrm{ekor}$, fase grower 105 kg/ekor, induk betina 141 kg/ekor dan pejantan $122 \mathrm{~kg} / \mathrm{ekor}$.

Rata-rata besarnya keuntungan yang diperoleh peternak sebesar Rp.1.512.367/ekor/periode produksi. Hasil analisis menunjukkan rata-rata keuntungan per tahun Rp. 13.611.309 atau ratarata per bulan sebesar Rp.1.944.472.

\section{Efisiensi Penggunaan Input}

Penggunaan input bahan pakan tidak efisien. Hal tersebut terlihat pada nilai NPM $<1$. Artinya peternak babi perlu mengurangi pemberian pakan pada fase grower, pejantan induk kering, induk bunting dan induk menyusui. Rata-rata efisiensi penggunaan input pakan yang dilihat dari nilai produk marjinal dapat dilihat pada Tabel 2.

Tabel 2. Nilai Produk Marjinal Penggunaan Input Pakan

\begin{tabular}{lccccc}
\hline \multicolumn{5}{c}{ Nilai Produk Marjinal (NPM) } \\
\hline Input makanan & Grower & Pejantan & $\begin{array}{c}\text { Induk } \\
\text { Kering }\end{array}$ & $\begin{array}{c}\text { Induk } \\
\text { Bunting }\end{array}$ & $\begin{array}{c}\text { Induk } \\
\text { Menyusui }\end{array}$ \\
\hline Butiran & - & - & - & - & - \\
Jagung & $-0,28$ & 0 & 0,66 & $-0,05$ & 0,09 \\
Dedak & 0,41 & $-0,01$ & 0,29 & 0,35 & $-0,07$ \\
Konsentrat & $-0,14$ & 0 & 0,33 & $-0,09$ & $-0,47$ \\
Tepung ikan & 0 & - & - & 0 & - \\
Bungkil & - & - & - & 0 & - \\
\hline
\end{tabular}


Input optimum merupakan input menghasilkan bobot badan tinggi yang paling kecil yang diberikan pada usaha peternakan babi di pada ternak babi dan menghasilkan bobot badan yang maksimal. RataKecamatan Tareran dapat dilihat pada Tabel 3.

rata pemberian input pakan yang

Tabel 3. Rata-rata Penggunaan Input Optimum

\begin{tabular}{lccccc}
\hline \multicolumn{5}{c}{ Input } \\
\hline Jenis Ternak & $\begin{array}{c}\text { Berat } \\
\text { Badan } \\
(\mathrm{Kg})\end{array}$ & $\begin{array}{c}\text { Jagung } \\
(\%)\end{array}$ & $\begin{array}{c}\text { Dedak } \\
(\%)\end{array}$ & $\begin{array}{c}\text { Konsentrat } \\
(\%)\end{array}$ & $\begin{array}{c}\text { Total } \\
(\%)\end{array}$ \\
\hline Grower & 120 & 48,26 & 25,86 & 25,86 & 100 \\
Pejantan & 125 & 33,87 & 33,87 & 32,25 & 100 \\
Induk Kering & 160 & 37,50 & 18,75 & 18,75 & 100 \\
Induk Bunting & 170 & 50,06 & 30,01 & 19,92 & 100 \\
Induk & 170 & 57,33 & 28,44 & 14,22 & 100 \\
Menyusui & & & & & \\
\hline
\end{tabular}

\section{KESIMPULAN}

Berdasarkan hasil penelitian dapat disimpulkan bahwa :

Usaha Ternak Babi di Kecamatan Tareran Kabupaten Minahasa Selatan memberikan keuntungan sebesar Rp.13.611.309/periode/tahun.

Penggunaan input pakan pada usaha peternakan babi di Kecamatan Tareran tidak efisien, oleh sebab itu peternak perlu mengurangi pemberian pakan karena sudah berlebihan.

Penggunaan input optimum pada fase grower yaitu jagung 48,26\%, dedak $25,86 \%$, konsentrat $25,86 \%$ dengan bobot badan maksimum 120 kg. Pejantan memiliki bobot badan maksimum $125 \mathrm{~kg}$ dengan input optimum yaitu jagung 33,87\%, dedak 33,87\%, konsentrat 32,25\%. Induk kering memiliki bobot badan $160 \mathrm{~kg}$ dengan input optimum yaitu jagung 50,00\%, dedak 25,00\%, konsentrat $25,00 \%$. Induk bunting memiliki bobot badan $170 \mathrm{~kg}$, dengan input optimum yaitu jagung $50,06 \%$, dedak 30,01\%, konsentrat $19,92 \%$. Induk menyusui memiliki bobot badan $170 \mathrm{~kg}$, dengan input optimum yaitu jagung 57,33\%, dedak 28,44\% dan konsentrat $14,22 \%$.

\section{SARAN}

Berdasarkan hasil penelitian dapat disarankan, peternak harus lebih 
memperhatikan biaya operasional dan efisiensi pemberian pakan agar keuntungan yang diperoleh dari usaha ternak babi lebih meningkat.

\section{DAFTAR PUSTAKA}

Aritonang. 1993. Babi "Perencanaan dan Pengelolaan Usaha”. Penebar Swadaya. Jakarta.

Gultom, Y. 2007. Strategi Pengembangan Usaha Peternakan Babi. (Skripsi). Fakultas Peternakan Program Studi Sosial Ekonomi Institut Pertanian. Bogor

Mardalis, 2002 Metode Penelitian Suatu Pendekatan Proposal. Bumi Aksara. Jakarta.

Rahardi, F; I. Satyawibawa dan R.N. Setyowati. 1999. Agribisnis Peternakan. Cetakan Kelima. PT Penebar Swadaya (Anggota IKAPI). Jakarta.

Sihombing, D.T.H. 1997. Ilmu Ternak Babi. Gadjah Mada University Press. Yogyakarta.

Soekartawi. 2001. Analisis Usaha

Tani. Universitas Indonesia Press, Jakarta.

Sulistyawati. L. 2009. Pengaruh Upah Minimum Terhadap
Penyerapan Tenaga Kerja di Kotamadya Bogor Jawa Barat. Karya Ilmiah Fakultas Peternakan IPB. Bogor.

Sumangkut. 2006. Kontribusi Usaha Peternakan Babi Terhadap Pendapatan Rumah Tangga Petani Peternak di Kecamatan Kawangkoan.

(Skripsi).

Fakultas Peternakan Jurusan Sosial Ekonomi. UNSRAT. Manado. 
